\title{
ANALITIKA
}

Available online http://ojs.uma.ac.id/index.php/ analitika

Kontribusi dari Motif Cyber-relationship Terhadap Kecanduan

Internet pada Orang Dewasa

\section{Contribution of Cyber-relationship Motive to Internet Addiction in Adults}

\author{
Ursa Majorsy, Indria Hapsari, Vega Valentine, Aprilia Maharani Ayuningsih \\ Universitas Gunadarma, Indonesia \\ *Corresponding author: E-mail: ursa_majorsyi@yahoo.com
}

\begin{abstract}
Abstrak
Saat ini, internet telah menjadi kebiasaan sebagian besar kehidupan sosial manusia, terutama bagi orang dewasa. Kemudahan penggunaan internet mereda dalam aktivitas dunia maya, seperti berselancar. Daya tarik besar aktivitas berselancar di dunia maya membuat kecanduan internet menjadi fenomena yang menarik dan ramai untuk didiskusikan. Faktor psikologis yang terkait erat dengan kecanduan internet adalah motif hubungan cyber orang dewasa. Dalam penelitian ini, motif hubungan cyber difokuskan pada dimensi petualangan, dimensi escape dan dimensi asmara. Ini bertujuan untuk mengetahui motif sosial di balik perilaku kecanduan dewasa terhadap internet. Penelitian ini menggunakan regresi sederhana terhadap 70 peserta dengan rentang usia 22-44 tahun. Hasilnya menunjukkan bahwa motif hubungan cyber berkontribusi $31,6 \%$ terhadap kecanduan internet untuk orang dewasa. Analisis lebih lanjut menunjukkan bahwa dimensi escape dari motif hubungan cyber memiliki kontribusi paling besar terhadap kecanduan internet, dibandingkan dengan petualangan dan asmara.
\end{abstract}

Kata Kunci: Kecanduan Internet, Motif Cyber-Relationship, Dewasa

\section{Abstract}

Nowadays, internet has become a habitual part of human social life, especially for adults. The convenience of internet use lulls adults in cyberspace activity, such as surfing. The great appeal of surfing activity in cyberspace makes addiction to the internet an interesting and bustling phenomenon to be discussed. A psychological factor that closely related to internet addiction is the adults' cyber-relationship motive. In this study, cyber-relationship motive is focused on adventure dimension, escape dimension and romance dimension. It aims to determine the social motives behind adult addiction behavior towards the internet. This study used a simple regression of 70 participants with range of age 22-44 years. The result showed that cyber-relationship motive is contributing $31.6 \%$ to internet addiction for adults. Further analysis showed that escape dimension of cyber-relationship motive has the most contribution to internet addiction, compared to adventure and romance.

Keywords: Internet Addiction, Cyber-Relationship Motive, Adults

How to Cite: Majorsy, U., Hapsari, I., Valentine, V., \& Maharani, Aprilia (2017), Contribution of Cyberrelationship Motive to Internet Addiction in Adults, ANALITIKA, Vol 9 (2): 91 - 96 
Ursa Majorsy, Indria Hapsari, Vega Valentine, Aprilia Maharani Ayuningsih, Contribution of Cyberrelationship Motive to Internet Addiction in Adults

\section{INTRODUCTION}

Living in an era of rapidly emerging technologies make individuals become dependent on technology. One of the phenomenon of technology today are people always busy discussing about the internet. Internet usage is immense in every age group around the world in every single thing. There are more than three billion internet users worldwide (Internet World Stats, 2014). The presence of the internet in human life can provide abundance of things, as the internet allows each individual to share information and speed them up in performing various activities. The role of internet in the human life resulting an increased number of internet users in Indonesia. Reported from IPJII, the number of internet users in Indonesia in 2017 are 88.1 million users and continues to increase by 44.6 million users within 2014-2016 (APJII, 2017).

However, the ease of accessing the internet on the other hand can bring problems in human life or even destroy the individual's life. In some, the use of internet can become uncontrollable and compulsive, causing individuals to become dependent, and begin to behave unhealthily when accessing the internet. Unhealthy behavior shown when accessing the internet is known as internet addiction. Internet addiction is one form of behavioral addiction that according to Shaw and Black (2008), characterized by lack of individual ability to exercise selfcontrol, also the impulse or behavior which take up computer usage and internet access would cause stress on a person. In addition, according to Shapira, Lazoritz, Lessig, Gold, Goldsmith, Szabo, and Stein (2003) addiction to the internet also emerged with indicators such as the inability of individuals in limiting the use of the Internet, continuously using the internet despite experiencing social and academic problems and experiencing anxiety when internet access is limited.

Many things can cause an addiction to the internet. Personality is predicted as an important factor related to internet addiction (Weibel, Wissmath, \& Groner, 2010). This is because personality can significantly influence internet users' behavior. According to Kim, Sohn, and Choi, (2011) the way individuals adopt and use the internet is a function of their psychological and satisfactory needs. Therefore, the involvement of each Internet user's motive is very instrumental for determining how individuals behave using the internet, especially in individuals experiencing internet addiction. The internet is oftenly used to get an exciting experience, which in some individual point of view, can help them getting out of problems and anxiety. In addition, sharing and expressing feelings with online friends can be done easily without having to regret or confront. In other words, making friends through online world can help individuals distance themselves from the fear, stress or depression they experienced in the real world, but on the other hand getting closer to the addiction to the internet.

Some people, using the internet to build a friendship in cyberspace because of the inability to socialize in the real world. These individuals tend to look for similar people who can equip themselves through the virtual world (Bonebrake in Wang \& Chang, 2010). In addition to the results of research conducted by Amiel 
Ursa Majorsy, Indria Hapsari, Vega Valentine, Aprilia Maharani Ayuningsih, Contribution of Cyberrelationship Motive to Internet Addiction in Adults

and Shargent (2004) and Gombor and Vas (in Kalmus, Realo \& Siibak, 2011), it is known that people who are vulnerable to negative emotional experiences (anxious) will use the internet with friendship motives, as well to avoid loneliness (Butt \& Phillips, 2009). These reasons make the individual more interested in a new relationship in cyberspace or can be called as a cyber-relationship motive (Wang \& Chang, 2010). Furthermore, Wang and Chang (2010) share three big dimensions in cyber-relationship motive, namely adventure, escape to a virtual world and romance. In the adventure dimension there are indicators of anonymity, opportunities in finding new people, easy communication, curiosity, and emotional support. While in the escape to a virtual world dimension there are indicators of escape from the real world and social compensation. Furthermore, in the romance dimension there are indicators of love and also sexual partners. In this study, researchers try to focus on the role of personality i.e. the social motives of individuals to internet addiction.

\section{METHODOLOGY}

This research is a quantitative research with 70 respondents aged 22-44 years. Data collection in this research is obtained by using questionnaire method containing the list of respondents identity. Scale is used to obtain data in the form of respondents' answers. The scale is attached in a form of internet addiction scale and cyber-relationship motive. The cyber-relationship motive scale is adapted from Wang and Chang (2010) using 3 dimensions: the motive of adventure, escape and romance. The internet addiction scale is based on 8 interference criteria developed by Young in 1998 to diagnose Internet addiction by the name of The Internet Addiction Diagnostic Questionnaire (IADQ) (Young \& de Abreu, 2011). These are: (1) feeling preoccupied with the internet, (2) the need of extra time to achieve satisfaction while using the internet, (3) inability to control, reduce or stop using the internet, (4) feeling anxious, depressed, depressed or irritable when trying to reduce or discontinue internet usage, (5) accessing the internet longer than expected, (6) losing the nearest person, job, opportunity, education or career due to internet usage, (7) lying to families, therapists or the closest people to hide further engagement with the internet, and (8) using the internet as a way of solving problems or relieving feelings of helplessness, guilt, anxiety or depression.

The data obtained from the questionnaire will be processed using SPSS with simple regression analysis technique. Regression analysis technique is used to see whether internet addiction is being contributed or affected by cyberrelationship motive.

\section{RESULT AND DISCUSSION}

Based on the results, for the scale of cyber relationship motives, it is found that from the 29 items tested, 20 valid items are obtained with the discrimination of moving items between 0.300-0.704, the reliability value is 0.860 . As for the internet addiction scale, it is found that from 24 items tested, 22 valid items are obtained with discrimination items ranged between $0.373-0.805$ and the reliability value is 0.919 . 
Ursa Majorsy, Indria Hapsari, Vega Valentine, Aprilia Maharani Ayuningsih, Contribution of Cyberrelationship Motive to Internet Addiction in Adults

The significance of cyber relationship motive and internet addiction is as big as $(F=0,000)$, this means that the cyber relationship motives has a very strong role on internet addiction. Based on the results of the research, it can be concluded that the hypothesis proposed in this study are accepted, i.e. there is a role of cyber relationship motive toward internet addiction. Rsquare value obtained is 0.316 , this indicates that the cyber relationship motives accounted for $31.6 \%$ of internet addiction.

Furthermore, from each dimension of the cyber relationship motives, the escape dimension has the greatest contribution to internet addiction of $38.9 \%$. Then the $28.2 \%$ is from adventure dimension and the last dimension of romance is $12.3 \%$. Based on demographic data, it is known that $70 \%$ of participants are female and $30 \%$ male. There were $17.1 \%$ of married respondents and $82.9 \%$ single. The average respondent used his time to surf in cyberspace for one to three hours. It is also known that on average $70 \%$ of respondents access the internet every day.

The purpose of this study is to determine the role of social motives behind adult addiction behavior towards the internet. It is known that the significance between cyber-relationship motive and internet addiction variables is $(\mathrm{F}=0,000)$ which means that the motive of cyber relationships motives has a very strong role on internet addiction. Rsquare value obtained is 0.316 , this indicates that the cyber-relationships motives accounted for $31.6 \%$ of internet addiction. As one aspect of the individual personality, motive plays a role for the individual in behaving. Motives are the reasons behind the emergence of a behavior. According to Hardie and Tee (in Kalmus, Realo, \& Siibak, 2011) personality trait such as internet use motive can also act as a trigger of negative aspects of internet usage, such as addiction.

From the respondents, it is found that the motives contributing in cyberrelationship motives toward internet addiction is adventure, escape and romance. Furthermore, through each dimension of the cyber-relationship motive's variables, it is found that the escape dimension has the greatest contribution to internet addiction of $38.9 \%$. Thus, one thing that can cause an individual to be addicted to the internet is the motive for escape. This is corresponding to studies done by Rubin, Perse, and Barbato (1988), and Wang and Chang (2010), that communicating online can help a person break away from real world anxieties or disturbing activities. Escape from the real world to the virtual world, making individuals more comfortable and relax through dialogue or activities they do with others online. In addition, the factor that can cause the increasing relationships in virtual world is the fact that physical appearance and visual cues do not play an important role (McKenna \& Bargh, 2000), so that individuals who have difficulty in interacting with the environment and have feelings of lack of confidence will feel more comfortable to continue interacting in cyberspace. This is known as social compensation. According to Peter et al (Wang \& Chang 2010) individuals with a lack of social skills can use the internet as a form of social compensation. 
Ursa Majorsy, Indria Hapsari, Vega Valentine, Aprilia Maharani Ayuningsih, Contribution of Cyberrelationship Motive to Internet Addiction in Adults

In addition to escape motive, it is also found that motive of adventure is a motive of the dimensions of other virtual worlds, which has a substantial contribution to internet addiction by $28.2 \%$. This may be closely related to anonymity feature offered when accessing the internet. With the opportunity not to be known (anonymity) in the internet indirectly makes a person becomes more at ease and courageous in surfing the cyberspace. The existence of anonymity on the internet makes it easier for individuals to connect and interact to the virtual world, either with new individuals or with individuals they already known before. In corresponds to the opinion of Wang and Chang (2010) that this anonymity will make other people connect easily so as to establish a new relationship. The Internet can reduce impact of norms and social barriers that exist in two-way face-to-face communication. This will make individuals more free, open, and courageous in expressing their feelings and opinions on any topics which ususally considered taboo (Chou \& Peng, in Wang \& Chang, 2010). Thus, individuals are more likely to be attracted to others who have the same background, attitude, physical attraction and personality characteristics and with that similarity will form comfort, then the individual will be able to experiment with new roles that are usually uncomfortable to do.

Meanwhile, the romance dimension of cyber-relationship motive has the smallest contribution with only $12.3 \%$. This means that only a few individuals who use the internet as a partner or media to a romantic relationship. This is different from the results obtained by Daneback,
Mansson, and Ross (in Wang \& Chang 2010) which shows that in Sweden, the most popular activity when individuals surfing the internet is for sexual purposes.

Additional analysis that can be known from this research is, as much as $42.9 \%$ of respondents use the time to surf in the virtual world for one to three hours for each time for online. In addition, it is also found that $70 \%$ of the respondents access the internet every day. The results are in corespondence with what Levine (2000) says that the more time spent communicating in cyberspace, the more likely it will be to build relationships with others as well. The formation of intense cyberspace in the virtual world will eliminate one's doubts in forming such relationships, so that individuals will prefer to connect and communicate with cyberspace. As time goes by to interact in cyberspace, individuals tend to find others who are similar to them. In addition, it is also found that $70 \%$ of participants are women and $30 \%$ of men. There are $17.1 \%$ of married respondents and $82.9 \%$ single.

\section{CONCLUSION}

Based on the analysis, it can be concluded that cyber-relationship motive has a very significant role on internet addiction, especially in the escape dimension of cyber-relationships motive, followed by dimension of adventure and romance.

\section{REFERENCES}

IPJII (Asosiasi Penyelenggara Jasa Internet Indonesia).

https://apjii.or.id/content/read/39/264/Sur vei-Internet-APJII-2016. Diakses: 5 Agustus 2017.

Amiel, T. and Sargent, S. L. (2004). Individual differences in Internet usage motives. 
Ursa Majorsy, Indria Hapsari, Vega Valentine, Aprilia Maharani Ayuningsih, Contribution of Cyberrelationship Motive to Internet Addiction in Adults

Computers in Human Behavior, 20, 6, 711726.

Buckner, J. E. V., Castille, C. M., \& Sheets, T. L. (2012). The five factor model of personality and employees' excessive use of technology. Computers in Human Behavior, 28, 19471953.

Butt, S. \& Phillips, J. G. (2008). Personality and self reported mobile phone use. Computers in Human Behavior 24, 2, 346-36o.

Internet World Stats. (2014). Retrived from http://www.internetworldstats.com on 21 December 2014

Kalmus, V., Realo, A., \& Siibak, A. (2011). Motives for internet use and their relationships with personality traits and socio-demographic factors. TRAMES, $15(65 / 60), 4,385-403$

Kayis, A.R., Satici, S.A., Yilmaz, M.F., Simsek, D., Ceyhan, E., Bakioglu, F. (2016). Big fivepersonality trait and internet addiction: A meta-analytic review. Computers in Human Behavior, 63, 35-40

Kim, Yoojung., Sohn, Dongyoung., \& Choi, S. M. (2011). Cultural difference in motivations for using social network sites: A comparative study of American and Korean college students. Computers in Human Behavior, $27,1,365-372$

Landers, R. N., \& Lounsbury, J. W. (2006). An investigation of big five and narrow personality traits in relation to Internet usage. Computers in Human Behavior, 22, 283-293

Levine, D. (200o). Virtual attraction: what rocks your boat. CyberPsychology \& Behavior, 3, 565-573.

McKenna, K., \& Bargh, J. (200o). Plan 9 from cyberspace: the implications of the Internet for personality and social psychology. Personality and Social Psychology Review, 4, 57-75.

Parks, M. R., \& Floyd, K. (1996). Making friends in cyberspace. Journal of Communication, 46, 1, 80-97.

Rubin, R.B., Perse, E.M., Barbato, C.A. (1988). Conceptualitation and measurement of interpersonal communicational motive. Human Communication Research, 14, 4, 602-628

Shapira, N.A., Lazoritz, M.D., Lessig, M. C., Gold, M.S., Goldsmith, T.D., Szabo, S. T., \& Stein, D. J. (2003). Problematic internet use: Proposed classification and diagnostic criteria. Depression and anxiety, 17, 207-216
Shaw, M., \& Black, D.W. (2008). Internet addiction: Definition, assessment, epidemiology and clinical management. CNS Drugs, 22, 5, 353-365. https://www.ncbi.nlm.nih.gov/pubmed/183 99706

Wang, Chih-Chien., \& Chang, Ya-Ting. (2010). Cyber relationship motives: Scale development and validation. Social Behavior and Personality: An international journal, 38, 3, 289-300

Weibel, D., Wissmath, B., \& Groner, R. (2010). Motives for creating a private website and personality of Personal homepage owners in terms of extraversion and heuristic orientation. Cyberpsychology: Journal of Psychosocial Research on Cyberspace, 4, 1. https://cyberpsychology.eu/article/view/42 $34 / 3278$

Young, K. S. , \& de Abreu, C. N. (2011). Internet addiction: A handbook and guide to evaluation and treatment. New Jersey: John Wiley \& Sons, Inc 